
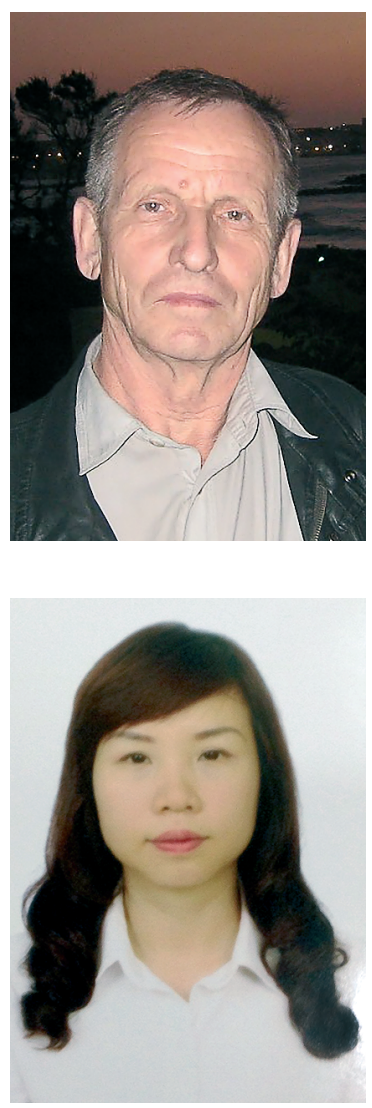

\section{Шаклеин Виктор Михайлович}

доктор филологических наук, профессор, заведующий кафредрой русского языка и методики его преподавания филологический фракультет, Российский университет дружбы народов 117198, Российская Федерация, г. Москва, ул. МиклухоМаклая, д.6, e-mail: shaklein_vm@pfur.ru

\section{Viktor M. Shaklein}

DSc in Philology, Professor, Head of the Russian Language and Methods of Teaching Department

Philological Faculty, Peoples' Friendship University of Russia 117198 Russia, Moscow, Miklukho-Maklaya Str., 6, e-mail: shaklein_vm@pfur.ru

\section{Нгуен Лан Фыонг \\ аспирант}

кафедра русского языка и методики его преподавания, фрилологический фракультет,

Российский университет дружбы народов

117198, Российская Федерация, г. Москва, ул. Миклухо-

Маклая, д. 6, e-mail: phuong24343@gmail.com

\section{Nguyen Phuong Lan}

PhD Student

Russian Language and Methods of Teaching Department, Philological Faculty, Peoples' Friendship University of Russia 117198 Russia, Moscow, Miklukho-Maklaya Str., 6. e-mail: phuong24343@gmail.com

\title{
ИНФОРМАТИВНЫЙ КОМПОНЕНТ КРЫЛАТЫХ ВЫРАЖЕНИЙ КОМЕДИИ А. С. ГРИБОЕДОВА «ГОРЕ ОТ УМА॥ С ПОЗИЦИИ ВЬЕТНАМСКОЙ ЯЗЫКОВОЙ ТРАДИЦИИ
}

\footnotetext{
Аннотация. Большое количество фраз из комедии А.С. Грибоедова «Горе от ума» являются крылатыми выражениями. На сегодняшний день они не теряют своей актуальности, благодаря, в том числе и смысловой точности, эмоциональной выразительности, особенностям национально-культурной семантики. Это подтверждают многочисленные примеры употребления цитат из комедии в средствах массовой информации, начиная от газет первой четверти XIX в. до современных текстов Интернета. Национальная специфика понимания значения этих выражений базируется на культурно-исторической базе, традициях российского общества. В русском и вьетнамском языках имеется значительное число подобных по-своему смысловому наполнению крылатых выражений. Это помогает более глубоко понять содержание текста грибоедовского произведе-
} 
ния. В обоих языках само понятие «крылатое выражение» имеет схожее определение. Различное понимание крылатых выражений в русской и вьетнамской лингвокультурах вызвано тем, что представители вьетнамской лингвокультуры воспринимают их смысл в контексте тесной связи с традициями, культурой, философией, религией, прошлым и настоящим Вьетнама.

Ключевые слова. Крылатое выражение, собственно авторские выражения, крылатизация, лингвокультурология, вьетнамская лингвокультура, семантизация, интерпретация.

Информация о статье. Дата поступления 16 марта 2017 г.; дата принятия к печати 28 апреля 2017 г.; дата онлайн-размещения 08 июня 2017 г.

\section{INFORMATIONAL COMPONENT OF ELOQUENT EXPRESSIONS IN A. S. GRIBOEDOV'S COMEDY "GORE OT UMA» (WOE FROM WIT) IN THE ASPECT OF VIETNAMESE LANGUAGE TRADITION}

\footnotetext{
Abstract. Many phrases from A.S. Griboedov's comedy "Gore ot Uma" (Woe from Wit) are eloquent phrases. They are still actual due to their accuracy, emotional effect, national and cultural semantics. This is proved by a great amount of citations taken from the comedy and used in mass media, newspapers of the 19th century and in modern Internet texts as well. The reader should be familiar with the Russian cultural and historical background, national traditions. The Russian and Vietnamese languages have similar eloquent phrases. This helps to understand Griboedov's comedy deeper. Both languages have a similar definition for eloquent phrases. These phrases are understood differently in the Russian and Vietnamese linguistic and cultural traditions because the Vietnamese understand them considering the Vietnamese culture, philosophy, religion, past and present.

Keywords. Eloquent phrase, author's phrases, eloquent phrases studies, cultural linguistics, Vietnamese linguistic culture, semantization, interpretation.

Article info. Received March 16, 2017; accepted April 28, 2017; available online June 08, 2017.
}

Значительное место в жизни, развитии языка того или иного народа занимают крылатые выражения. Благодаря устойчивым сочетаниям слов появляется возможность сжатого, но красноречивого выражения мыслей. Они также позволяют в яркой языковой форме дать точное, эмоциональное описание лингвокультурной ситуации, человеческих отношений. В любом языке мира можно выделить сочетания определённых слов, «готовые комбинации» слов, используя которые говорящий имеет воз- можность в сжатой, но понятной форме выразить свое отношение, свои мысли по поводу происходящих событий.

Одной из особенностей крылатых выражений является их двуплановость с точки зрения смысла: кроме прямого значения, они могут иметь иносказательное значение, т. е. употребляться в переносном смысле. Однако А. А. Потебня утверждал, что в процессе использования крылатые выражения «следует употреблять очень осмотрительно, потому что, 
собственно говоря, художественное произведение и создание природы принадлежат не к одной и той же области и несоизмеримы одним и тем же масштабом, точно так как чувственный образ и представление его в слове не принадлежат к одному continuum'y форм душевной жизни» [1, с. 166].

Актуальной проблемой в изучении крылатых выражений является вопрос о трактовке понятия «крылатое выражение» в контексте русской и вьетнамской филологии. Изучение национальной семантики крылатых выражений в комедии «Горе от ума» A. С. Грибоедова с позиции иной языковой национальной традиции, в частности, вьетнамской лингвокультуры, представляет особый интерес, так как позволяет детально рассмотреть различия в усвоении таких выражений, основанных на лингвистической, культурологической базе носителей русского и вьетнамского языков. Анализ этих выражений с позиции вьетнамской лингвокультуры, в том числе и с вьетнамскими крылатыми выражениями, позволит определить национальные особенности их семантики.

Как российские, так и вьетнамские лингвисты занимаются исследованием процессов крылатизации, специфики крылатых выражений [2-10]. Так, крылатые выражения из комедии «Горе от ума» изучались в контексте уточнения их трактовки, выявления культурной значимости С точки зрения развития русского языка. Выделялись «говорящие» фамилии, в том числе и в контексте истории создания произведения. Рассматривались примеры фрункционирования этих выражений в современной речи [11-18]. Кроме того, на сегодняшний день известно большое количество словарей и сборников, посвященных афроризмам и крылатым выражениям А. С. Грибоедова [19; 20]. Изучением грибоедовской комедии занимались филологи, лингвисты, культурологи, литературоведы - текст произведения рассматривался с точки зрения герменевтики, риторики, влияния языка комедии на развитие русской речи, литературного языка [21-25]. Кроме того, в данной статье также использованы работы, посвящённые лингвокультурологическому аспекту в изучении русского языка, так как они позволяют лучше понять роль крылатых выражений в этом языке [26-29].

Цель данной статьи - определить национальные особенности трактовки семантики крылатых выражений, присутствующих в комедии, с позиции носителя вьетнамской лингвокультуры.

Основой исследования послужили работы В. В. Виноградова «Об основных типах фразеологических единиц в русском языке», С. Г. Шулежковой «Крылатые выражения русского языка, их источники и развитие», Е. М. Верещагина, В. Г. Костомарова «Язык и культура», И. Я. Пака «Лингвокультурология как следствие интеграции наук. Принципы лингвокультурологического анализа», Во Минь Хай «Исследование культурной традиции юга и севера в литературном языке Вьетнама в средних веках». Основываясь на предложенном И. Я. Паком построении семантических полей, включающих в себя микрополя, которые связаны с другими языковыми категориями (экспрессивностью, эмотивностью, оценочностью, интенсивности 
и др.), нами был проведён анализ, описание фраз и выражений, ставших крылатыми выражениями.

Крылатые выражения, являясь частью фразеологии русского языка, тем не менее, отличаются от фразеологизмов. Фразеологизмы, как известно, представляют собой устойчивое сочетание слов, которое имеет определенное не всегда объективное значение, а также не имеет автора. Анализ статьи Т. Г. Варченко и Л. А. Рачковской «К вопросу о терминологическом аппарате и становлении крылатологии как самостоятельной лингвистической дисциплины» позволяет утверждать, что крылатые выражения представляют собой высказывания известных людей, исторических личностей, цитаты из литературных произведений, которые прочно вошли в речь, выступая определением того или иного действия, события, предмета. В словаре С. И. Ожегова дается следующее определение: «Крылатые слова - образные, меткие выражения, изречения, вошедшие в общее употребление» [30, с. 315].

По всей видимости, «при исследовании источника крылатого выражения разграничиваются два процесса: процесс формирования крылатого выражения («крылатизация» цитаты) и функционирование его в устной речи или в литературе». Основными причинами крылатизации сочетания различных слов являются: «1) постоянное употребление свободных сочетаний слов не в прямом, а в обобщенном и образнопереносном значении; 2) появление в свободном сочетании слов слова связанного, фразеологически ограниченного употребления; 3) выражение свободным сочетанием слов единого понятия, актуального для данной исторической эпохи» [15, с. 113]. Также важно учитывать тот факт, что процесс крылатизации различных выражений возникает благодаря личным качествам автора текста, силе, актуальности его литературного языка, творческого видения, социальной значимости затрагиваемой в литературном произведении темы, большой популярности у читателей в любой период времени.

Созданные А. С. Грибоедовым словосочетания, предложения, ставшие впоследствии крылатыми выражениями, затрагивали различные темы, связанные с жизнью общества: человеческие отношения, социальные, национальные, политические проблемы, существовавшие в первой половине XIX века. В произведении автор обращался ко многим символам, иллюстрирующим современное ему общество, что способствовало появлению собственных авторских оригинальных выражений, ставших затем крылатыми выражениями русского языка. Поэтический язык автора отличают меткость, лаконичность, афористичность. А. С. Пушкин так отзывался о данной комедии: «Теперь вопрос. В комедии «Горе от ума» кто умное действующее лицо? ответ: Грибоедов. А знаешь ли, что такое Чацкий? Пылкий и благородный и добрый малый, проведший несколько времени с очень умным человеком (именно с Грибоедовым) и. напитавшийся его мыслями, остротами и сатирическими замечаниями. Bce, что говорит он, - очень умно. «...» Между мастерскими чертами этой прелестной комедии - недоверчивость Чацкого в любви Софии к Молчалину прелестна! — и как натураль- 
но! Вот на чем должна была вертеться вся комедия, но Грибоедов, видно, не захотел - его воля. О стихах я не говорю: половина - должны войти в пословицу» [31, с. 153].

С. Г. Шулежкова пишет, что термин «крылатое выражение» в науку ввёл немецкий исследователь Георг Бюхман: «Крылатое слово - это постоянно воспроизводимое в широких кругах изречение, выражение или имя безразлично какого языка, исторический источник или литературное происхождение которого известно (доказуемо)» [Там же, с. 6]. Она предлагает выделять пять признаков крылатых выражений: «1) связь с источником (автором, персонажем, реальным событием); 2) раздельнооформленность (состоят из двух или более компонентов, связанных по грамматическим законам языка); 3) воспроизводимость (не создаются в процессе общения, а воспризводятся как готовые целостные единицы); 4) устойчивость компонентного состава и грамматической структуры (не исключающей вариантности); 5) устойчивость семантики, закрепленной за данным выражением» [4, с. 35].

Цитаты из произведения перешли в разряд крылатых выражений в соответствие с 3 пунктами крылатизации, названными С. Г. Шулежковой, а именно: 1) смысловая насыщенность, так как благодаря своей языковой выразительности, тончайшим языковым, культурным оттенкам, приобрели в русском языке такое значение, которое роднит их с пословицами и поговорками; 2) образно-эмоциональная окрашенность; 3) жизненная актуальность вне зависимости от эпохи, так как они используются в русском языке на протяжении почти двухсот лет, для образного описания того или иного события.

Крылатые выражения из комедии стали известными в обществе благодаря своей опоре на русскую традицию. Многим из них можно найти аналогии среди русских пословиц, поговорок. Высказывание автора о несправедливом суде «А судьи кто?» находит своё отражение в пословице «Судья в суде - что рыба в пруде» ${ }^{1}$ [32]. Цитата из комедии о неосторожно сказанном слове «Ах, злые языки страшнее пистолета» является авторской иллюстрацией народного высказывания «Слово не воробей, вылетит - не поймаешь» ${ }^{2}$ [Там же]. Выражение «С чувством, С толком, с расстановкой» в народной русской традиции представляет собой поговорку о важности внимательного отношения к труду - «Семь раз отмерь, один раз отрежь» ${ }^{3}$ [Там же]. Русская пословица «Заставь дурака богу молиться, он и лоб расшибет», обличающая слепую веру, была выражена во фрразе «Блажен кто верует, тепло ему на свете». О том, что гордость отсутствует у смелых людей, сказано в поговорке «Храброму длинная шпага не нужна» ${ }^{4}$. У А. С. Грибоедова можно встретить высказывание, отражающее народную традицию - «Велите ж мне в огонь, пойду как на обед» [Там же]. Русская пословица о важности сохранения индиффрерентных отношений во время работы с начальником и сослуживцами «По службе ни друга, ни недруга», также нашла своё отражение в комедии, вопло-

\footnotetext{
${ }^{1}$ Пословицы.py. URL: http://posloviz.ru/.

2 Там же.

3 Там же.

4 Там же.
} 
тившись в крылатом выражении «Служить бы рад, прислуживаться тошно ${ }^{5}$ [Там же]. А. С. Грибоедов, являясь представителем русской культуры, иллюстрировал в своём творчестве традиции, обычаи, философию народа, превратив их в известные крылатые выражения.

Во вьетнамской лингвистике в последние годы также уделяется внимание изучению крылатых выражений. Хоанг Фэ в «Словаре вьетнамского языка» утверждает: «Крылатые выражения - это крылатые слова, передающиеся народом из поколения в поколение» [33, с. 218]. «Словарь китайско-вьетнамского языка» под редакцией Дао Зуи Ань дает следующие определение: «Крылатые выражения - это яркие сочетания слов, созданные уважаемыми людьми» [34, с. 93]. Данное определение показывает, что во вьетнамской лингвокультуре важны не только сами крылатые выражения, но и их смысловое наполнение, языковая выразительность. Для носителя вьетнамской культуры важна личность создавшего крылатое выражение. Процесс использования таких выражений для представителя вьетнамской лингвокультуры становится своего рода преклонением перед его создателем.

Нгуен Ньы И в большом словаре вьетнамского языка, описывая понятие «крылатое выражение», делает акцент на личности создателя: «Крылатое выражение - это небольшое высказывание, которое даёт жизненное или философское описание различным событиям. Создателем крылатого выражения является известный, уважае-

\footnotetext{
${ }^{5}$ Пословицы.py. URL: http://posloviz.ru/.
}

мый человек, например: фрилософ, политик, ученый, писатель, артист» $[33$, c. 523].

Нго Тхи Тху Тхай приводит дополненное описание понятия «крылатое выражение» с учётом выводов предыдущих исследователей: «крылатые выражения делятся по видам, т. е. могут представлять собой пословицы, идиомы, афоризмы, лексически неделимые обороты, простые предложения, имеющие в своём составе крылатое слово» [34, с. 10].

Проанализировав мнения современных исследователей, можно сделать вывод о том, что во вьетнамском языке крылатые выражения представляют собой высказывания известных, исторических личностей, имеющие философское значение, передаваемые народом из поколения в поколение. Кроме того, во вьетнамском языке крылатыми выражениями могут быть пословицы, идиомы, афроризмы, неделимые лексические обороты, простые предложения, в которых присутствует крылатое слово.

На наш взгляд, определения крылатого выражения в русской и вьетнамской лингвокультурах схожи. В русском и вьетнамском языках оно представляет собой часто употребляемое высказывание, опирающееся на литературный или исторический источник, связанное с известной исторической личностью. Основное отличие понимания крылатого выражения в русской и вьетнамской культурах заключается в различном отношении к личности создателя выражения. Известно, что в русской культуре популярные крылатые выражения часто теряют в сознании народа связь с их создателем. Но- 
сители русской культуры нередко не задумываются о личности того, кто являлся автором такого выражения. При этом можно отметить утрату связи этого выражения с контекстом произведения, в котором оно появилось, в то время как во вьетнамской лингвокультуре крылатые выражения прочно ассоциируются с личностью их создателя. Подобное отношение к крылатым выражениям даёт возможность носителю вьетнамской культуры связать семантическую составляющую выражения со временем его создания, т. е. со временем жизни его создателя, что помогает расширить границы их трактовки в процессе использования.

С точки зрения русской лингвокультурологии, анализ крылатых выражений даёт возможность выявления культурной информации, значимой для русского общества. Закреплённые в устойчивых языковых формах, мысли, чувства, переживания автора, они представляют собой философию национального языка, в которой выражается дух и своеобразие нации. По утверждению В. Н. Телия, крылатые выражения - это «зеркало, в котором лингвокультурологическая общность идентифицирует свое национальное самосознание» [15, с. 82]. Она отмечала взаимосвязь языка и культуры, утверждала, что язык и культура могут быть связаны по следующему принципу: «1) культура, как и язык, - это формы сознания, отображающие мировоззрение человека; 2) культура и язык существуют в диалоге между собой; 3) субъект культуры и языка - это всегда индивид или социум, личность или общество: 4) нормативность - общая для культуры и языка черта; 5) историзм - одно из существенных свойств культуры и языка; 6) культуре и языку присуща антиномия динамика - статика» [29, с. 225-226].

Во вьетнамской лингвокультурологии крылатые выражения рассматриваются как высказывания, тесно связанные с культурным, историческим контекстом. Во Минь Хай утверждает, что крылатые выражения входят в систему «культурного языка» Вьетнама: «Все исторические, литературные высказывания должны быть рассмотрены в контексте их лингвокультурологического значения и в связи с литературным языком. Культурный язык представляет собой язык, связанный с культурой, историей, традицией народа» [9]. Автор представляет «культурный язык» как своеобразные культурные слои, каждый из которых имеет тесную связь с историческим контекстом, а также с высказываниями исторических личностей, что позволяет утвердить связь крылатых выражений с «культурным языком» народа. Исследователь утверждает, что понимание культурного, исторического, литературного контекста способствует возникновению максимально точного понимания крылатого выражения, а также корректного его использования.

Опираясь на мнение В. Н. Телия и Во Минь Хай, попытаемся выявить особенности восприятия крылатых выражений из комедии «Горе от ума» на фоне вьетнамской лингвокультуры. В данной таблице представлены: 1. Описание крылатых выражений с позиции русской лингвокультуры; 2. Описание крылатых выражений с позиции вьетнамской лингвокультуры. 
Вопросы теории и практики журналистики. 2017. Т. 6. № 3. С. 388-405

\begin{tabular}{|c|c|c|c|}
\hline № & $\begin{array}{l}\text { Семантическое описание } \\
\text { крылатых выражений с } \\
\text { позиции русской лингво- } \\
\text { культуры }\end{array}$ & $\begin{array}{l}\text { Крылатые } \\
\text { выражения } \\
\text { комедии } \\
\text { «Горе от } \\
\text { ума» }\end{array}$ & $\begin{array}{l}\text { Семантическое описание } \\
\text { крылатых выражений с по- } \\
\text { зиции вьетнамской лингво- } \\
\text { культуры }\end{array}$ \\
\hline 1 & $\begin{array}{l}\text { Обобщённое обо-значе- } \\
\text { ние, характе-ризующее } \\
\text { людей, с элементами } \\
\text { оценки }\end{array}$ & & $\begin{array}{l}\text { Конкретные значения, } \\
\text { опи-сывающие характер, } \\
\text { отноше-ние, эмоции по } \\
\text { отношению к событиям, } \\
\text { людям }\end{array}$ \\
\hline & 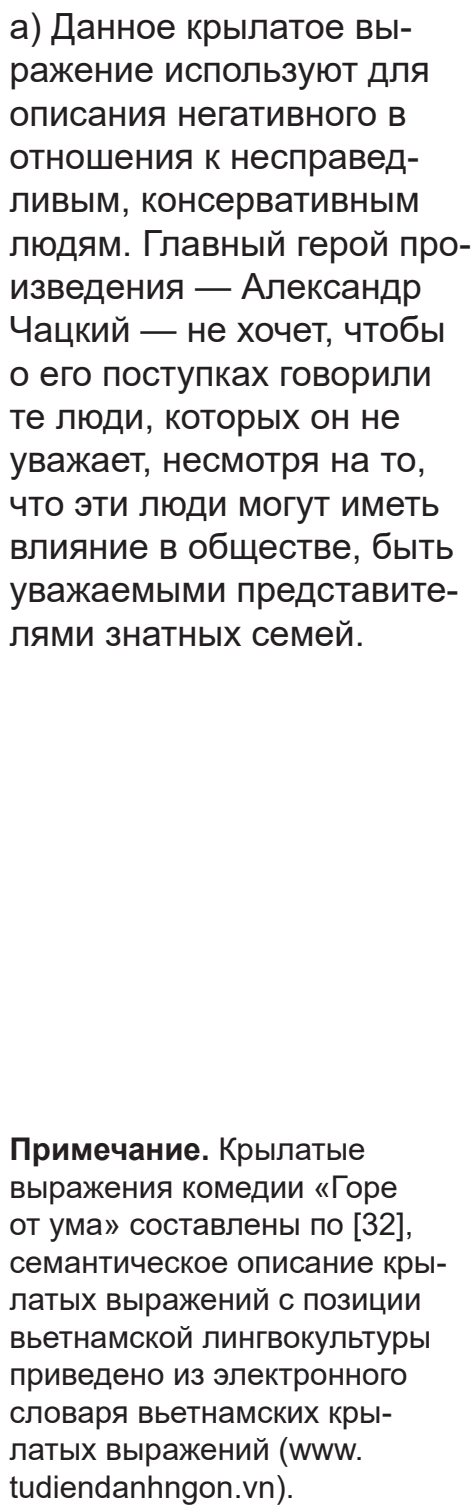 & $\begin{array}{l}\text { а) «А } \\
\text { судьи } \\
\text { кто?» }\end{array}$ & $\begin{array}{l}\text { a) С точки зрения вьет- } \\
\text { намской лингвокультуры } \\
\text { данное крылатое выра- } \\
\text { жение будет трактовано } \\
\text { иначе. Во вьетнамском } \\
\text { языке существуют два кры- } \\
\text { латых выражения, с про- } \\
\text { тивоположным смыслом, } \\
\text { однако они наиболее } \\
\text { ярко отражают отношение } \\
\text { просвещенных молодых } \\
\text { людей к консервативному } \\
\text { старшему поколению: } \\
\text { 1. В произведении } \\
\text { “Красная судьба” писателя } \\
\text { Ву Чонг Фунга, главный } \\
\text { герой «Суан красных } \\
\text { волос» - бедный молодой } \\
\text { человек, который умеет } \\
\text { льстить, использовать в } \\
\text { личных целях знакомство } \\
\text { с пожилыми, уважаемыми, } \\
\text { состоятельными людьми. } \\
\text { Благодаря особенностям } \\
\text { своего характера Суан } \\
\text { становится главой одной } \\
\text { состоятельной семьи. } \\
\text { «Красная судьба» - кры- } \\
\text { латое выражение, которое } \\
\text { описывает бесталанно- } \\
\text { го молодого человека, } \\
\text { который чтит и умеет ис- } \\
\text { пользовать традиционные } \\
\text { ценности, }\end{array}$ \\
\hline
\end{tabular}




\begin{tabular}{|c|c|c|}
\hline & & $\begin{array}{l}\text { уважение, расположение } \\
\text { старших, неразумные } \\
\text { привычки богатых. Данное } \\
\text { крылатое выражение ис- } \\
\text { пользуют по отношению } \\
\text { к поколению к молодым, } \\
\text { интеллигентным, но не- } \\
\text { талантливым людям, } \\
\text { которые добивались своих } \\
\text { целей во вьетнамском } \\
\text { обществе в начале ХХ } \\
\text { века. } \\
\text { 2. Нам Као в произведении } \\
\text { «Чи Фео» - имя главного } \\
\text { героя - описал хорошего, } \\
\text { доброго молодого чело- } \\
\text { века, который стал самым } \\
\text { циничным, злым чело- } \\
\text { веком в своей деревне } \\
\text { из-за ложного обвинения } \\
\text { старого, уважаемого, бога- } \\
\text { того крестьянина. } \\
\text { Крылатое выражение } \\
\text { «Кто дает мне шанс } \\
\text { быть хорошим и добрым } \\
\text { человеком», которое при- } \\
\text { сутствует в конце } \\
\text { произведения, } \\
\text { используется для } \\
\text { описания человека, } \\
\text { который под гнётом обще- } \\
\text { ства, не смог добиться } \\
\text { своих целей. } \\
\text { Данные крылатые выра- } \\
\text { жения описывают то, как } \\
\text { общество, время влияют } \\
\text { на судьбы двух главных } \\
\text { героев. }\end{array}$ \\
\hline $\begin{array}{l}\text { б) Выражение удивления } \\
\text { при неожиданной встрече с } \\
\text { кем-либо, к кому относятся } \\
\text { с иронией: }\end{array}$ & \begin{tabular}{|l|} 
б) «Ба! \\
Знакомые \\
все лица».
\end{tabular} & $\begin{array}{l}\text { б) Во вьетнамском языке } \\
\text { существуют крылатые вы- } \\
\text { ражения, которые описы- } \\
\text { вают искреннее удивление } \\
\text { при неожиданной встрече } \\
\text { со знакомыми людьми. }\end{array}$ \\
\hline
\end{tabular}




\begin{tabular}{|c|c|c|c|}
\hline & $\begin{array}{l}\text { в) Название собственно } \\
\text { оценки, в данном контексте } \\
\text { отрицательной }\end{array}$ & $\begin{array}{l}\text { в) «Герой } \\
\text { не моего } \\
\text { романа». }\end{array}$ & $\begin{array}{l}\text { в) Крылатые выраже- } \\
\text { ния вьетнамского языка } \\
\text { часто выражают не только } \\
\text { описание с отрицательной } \\
\text { коннотацией, но также со- } \\
\text { держат в себе насмешку, } \\
\text { иронию. }\end{array}$ \\
\hline & $\begin{array}{l}\text { г) Утверждение того, что } \\
\text { неосторожно сказанное } \\
\text { слово может обидеть че- } \\
\text { ловека, оказать большое } \\
\text { влияние на его дальней- } \\
\text { шую судьбу }\end{array}$ & $\begin{array}{l}\text { г) «Ах, } \\
\text { злые } \\
\text { языки } \\
\text { страшнее } \\
\text { пистоле- } \\
\text { та». }\end{array}$ & $\begin{array}{l}\text { г) Похожие крылатые вы- } \\
\text { ражения во вьетнамском } \\
\text { языке имеют содержат } \\
\text { в себе только предосте- } \\
\text { режение от обиды, они } \\
\text { используются также, чтобы } \\
\text { оскорбить человека со } \\
\text { «злым» языком. Дополни- } \\
\text { тельное значение у подоб- } \\
\text { ных крылатых выражений } \\
\text { появилось во времена ре- } \\
\text { прессий, организованных } \\
\text { французскими колониста- } \\
\text { ми в 1935-1940 годах. } \\
\text { Значение данных крыла- } \\
\text { тых выражений трансфор- } \\
\text { мировалось под влиянием } \\
\text { времени и истории. }\end{array}$ \\
\hline 2 & $\begin{array}{l}\text { Обобщённое выражение } \\
\text { отношения к жизни }\end{array}$ & & $\begin{array}{l}\text { Философрское отношение } \\
\text { к вере, человеку с точки } \\
\text { зрения буддистской тради- } \\
\text { ции }\end{array}$ \\
\hline & $\begin{array}{l}\text { а) Умному человеку } \\
\text { нелегко жить в непонимаю- } \\
\text { щем его обществе }\end{array}$ & $\begin{array}{l}\text { а) «Горе от } \\
\text { ума». }\end{array}$ & $\begin{array}{l}\text { а) Во вьетнамской культуре } \\
\text { присутствуют крылатые } \\
\text { выражения с идентичным } \\
\text { значением, которые описы- } \\
\text { вают недостатки традици- } \\
\text { онного общества. }\end{array}$ \\
\hline & $\begin{array}{l}\text { б) Любое действие чело- } \\
\text { века должно быть обдума- } \\
\text { но, работа должна быть } \\
\text { сделана ответственно. }\end{array}$ & $\begin{array}{l}\text { б) «С } \\
\text { чувством, } \\
\text { с толком, с } \\
\text { расстанов- } \\
\text { кой». }\end{array}$ & $\begin{array}{l}\text { б) Во вьетнамском языке } \\
\text { существует крылатое вы- } \\
\text { ражение, заимствованное } \\
\text { из китайского языка, при- } \\
\text { писываемое Конфуцию. В } \\
\text { нём говорится о том, что } \\
\text { человек становится акку- } \\
\text { ратным, когда серьезно } \\
\text { относится ко всем своим }\end{array}$ \\
\hline
\end{tabular}




\begin{tabular}{|c|c|c|}
\hline & & $\begin{array}{l}\text { действиям. «Много учись, } \\
\text { настойчиво проси, аккурат- } \\
\text { но думай, ясно рассуждай, } \\
\text { изо всех сил работай». } \\
\text { Данное крылатое вы- } \\
\text { ражение иллюстрирует } \\
\text { важность внимательного } \\
\text { отношение к слову, делу, } \\
\text { значению поступков. }\end{array}$ \\
\hline $\begin{array}{l}\text { в) Интересные, приятные } \\
\text { новости могут быть ложью }\end{array}$ & $\begin{array}{l}\text { в) «Свежо } \\
\text { предание, } \\
\text { да верится } \\
\text { с трудом». }\end{array}$ & $\begin{array}{l}\text { в) Во вьетнамском языке } \\
\text { существует крылатое вы- } \\
\text { ражение с похожим значе- } \\
\text { нием. Оно имеет связь с } \\
\text { философрией представите- } \\
\text { лей азиатских, буддистских } \\
\text { культур. Тхуи Ву говорил: } \\
\text { «я очень редко испытываю } \\
\text { чувство веры в кого-то. } \\
\text { Такие люди как я одиноки } \\
\text { и долго живут. Это не из-за } \\
\text { мнительности или каприза, } \\
\text { а из-за того, что я не } \\
\text { чувствую покоя. Этот мир } \\
\text { очень огромный и чужой, } \\
\text { человек, которому я могу } \\
\text { доверять, маленький». }\end{array}$ \\
\hline $\begin{array}{l}\text { г) Ироничное высказыва- } \\
\text { ние о том, кто легковерно } \\
\text { относится к различным не- } \\
\text { правдоподобным теориям }\end{array}$ & $\begin{array}{l}\text { г) } \\
\text { «Блажен, } \\
\text { кто } \\
\text { верует». }\end{array}$ & $\begin{array}{l}\text { г) Во вьетнамском языке } \\
\text { существуют ироничные } \\
\text { крылатые выражения по } \\
\text { отношению к верующим, } \\
\text { но также присутствуют } \\
\text { высказывания, иллюстри- } \\
\text { рующие уважительное } \\
\text { отношение к безгранично } \\
\text { верующим людям. Подоб- } \\
\text { ный фракт связан с тем, что } \\
\text { 90\% населения Вьетнама } \\
\text { долгое время были сто- } \\
\text { рон-никами абсолютной } \\
\text { монархии или буддистами. } \\
\text { Философия буддизма под- } \\
\text { разумевает, что добрый } \\
\text { человек - это блаженный, } \\
\text { святой человек. }\end{array}$ \\
\hline
\end{tabular}




\begin{tabular}{|c|c|c|c|}
\hline 3 & $\begin{array}{l}\text { Выражения надежды, } \\
\text { желания }\end{array}$ & & $\begin{array}{l}\text { Возвышенное отношение к } \\
\text { труду, связанное с феодаль- } \\
\text { ным прошлым и коммунисти- } \\
\text { ческим настоящим Вьетнама }\end{array}$ \\
\hline & $\begin{array}{l}\text { а) Лучше держаться по- } \\
\text { дальше от особого внимания } \\
\text { людей, от которых зави-сишь }\end{array}$ & $\begin{array}{l}\text { а) «Минуй } \\
\text { нас пуще } \\
\text { всех } \\
\text { печалей } \\
\text { и барский } \\
\text { гнев, и } \\
\text { барская } \\
\text { любовь». }\end{array}$ & $\begin{array}{l}\text { а) Во вьетнамской культуре } \\
\text { есть крылатые выражения } \\
\text { с аналогичным значение, } \\
\text { т. к. во Вьетнаме долгее } \\
\text { время существовала фрео- } \\
\text { дальная форма правления, } \\
\text { при которой власть имущие } \\
\text { могли решать судьбу других } \\
\text { людей. }\end{array}$ \\
\hline & $\begin{array}{l}\text { б) приятно заниматься } \\
\text { любимым делом, но непри- } \\
\text { ятно раболепствовать ради } \\
\text { получения уважения со } \\
\text { стороны общества }\end{array}$ & $\begin{array}{l}\text { б) } \\
\text { «Служить } \\
\text { бы рад, } \\
\text { прислу- } \\
\text { живаться } \\
\text { тошно». }\end{array}$ & $\begin{array}{l}\text { б) Крылатые выражения } \\
\text { со схожим значением при- } \\
\text { сутствуют во вьетнамском } \\
\text { языке. Благодаря социали- } \\
\text { стическому строю, существу- } \\
\text { ющему сейчас во Вьетнаме, } \\
\text { любой гражданин имеет воз- } \\
\text { можность работать честно, с } \\
\text { удовольствием, не являясь } \\
\text { при этом чьим-то слугой. }\end{array}$ \\
\hline & $\begin{array}{l}\text { в) выражение желания лени- } \\
\text { вого человека избавиться от } \\
\text { сложных дел }\end{array}$ & $\begin{array}{l}\text { в) «Под- } \\
\text { писано, } \\
\text { так с плеч } \\
\text { долой». }\end{array}$ & $\begin{array}{l}\text { в) Во вьетнамском языке есть } \\
\text { крылатые выражения с таким } \\
\text { же значением. Они исполь- } \\
\text { зуются для описания людей, } \\
\text { безответственно относящих- } \\
\text { ся к своей работе. }\end{array}$ \\
\hline & $\begin{array}{l}\text { г) желание совершить подвиг, } \\
\text { без гордости за свой поступок }\end{array}$ & $\begin{array}{l}\text { г) «Велите } \\
\text { ж мне в } \\
\text { огонь: } \\
\text { пойду как } \\
\text { на обед». }\end{array}$ & $\begin{array}{l}\text { г) Во вьетнамском языке } \\
\text { существуют различные кры- } \\
\text { латые выражения, описы- } \\
\text { вающие сильную, смелую } \\
\text { молодежь. Они применяются } \\
\text { в качестве описания идеоло- } \\
\text { гически настроенных юношей } \\
\text { и девушек, живших в XX веке, } \\
\text { а также по отношению к со- } \\
\text { временным молодым людям. } \\
\text { Наиболее ярким из подобных } \\
\text { крылатых выражений являют- } \\
\text { ся слова Хо Ши Мина: «Наша } \\
\text { молодежь очень пылкая. } \\
\text { Если мы сумеем собрать эту } \\
\text { пылкость воедино и направ- } \\
\text { лять её в правильное русло, } \\
\text { то наша молодежь станет } \\
\text { сильной». }\end{array}$ \\
\hline
\end{tabular}


Выражения из комедии «Горе от ума» стали крылатыми благодаря особенностям русского языка, русской лингвокультурной традиции. Сами по себе они обладают совокупностью определённых признаков, которые отличают различные устойчивые языковые единицы. Однако они отличаются от других языковых единиц своим семантическим багажом: их значения тесно связаны с культурным и историческим контекстом, личностью автора, литературным произведением, временем создания, а также многими другими событиями, послужившими почвой для их возникновения. Десятки различных цитат из комедии обогатили русский язык.

А. А. Потебня справедливо подчеркивал, что «человек обращается внутрь себя сначала только от внешних предметов, познает себя сначала только вне себя; внутренняя жизнь всегда имеет для человека непосредственную цену, но сознается и уясняется исподволь и посредственно» [1, с. 185]. В комедии «Горе от ума» А. С. Грибоедов, показывая внутреннюю жизнь человека, иллюстрирует его мысли, чувства, желания, фрилософию в таких точных, эмоциональных высказываниях, которые впоследствии стали крылатыми выражениями. В языке, творческом видении автор сумел отразить культурные, социальные особенности общества, которые были характерны для начала XIX века. Некоторые исследователи утверждают, что данная комедия является одной из наиболее часто цитируемых: «Подтверждением нашего предположения могут служить многочисленные примеры употребления различных цитат из комедии в средствах массовой информации, от газет первой четверти XIX в. до современных текстов Интернета» [14, с. 44]. Неповторимая оригинальность авторского языка позволили появиться крылатым выражениям, которые и сегодня не теряют своей актуальности. Они используются в различных речевых ситуациях, обогащают русскую речь, делая её эмоционально насыщенной.

Крылатые выражения А. С. Грибоедова являлись стилистическим, художественным отображение нравов, моды эпохи, что делает их ценными как с лингвокультурологической, так и с исторической точки зрения. Существовавшее в России два века назад общество, его привычки, характер, взгляды, позволили автору затронуть в своём произведении такие темы, которые впоследствии стали бессмертными, что делает фразы из комедии актуальными и по сегодняшний день, несмотря на то, что современники приняли эту комедию неоднозначно, не оценив чрезмерную откровенность писателя, прямоту его взглядов. Одни приняли ее с восторгом и не видели никаких недостатков. Другие, например, русский критик М. А. Дмитриев так отзывался о главном герое комедии Чацком: «Мы видим в Чацком человека, который злословит и говорит все, что не придет в голову; естественно, что такой человек наскучит во всяком обществе, и чем общество образованнее, тем он наскучит скорее!», а язык произведения критик назвал «жестким, неровным и неправильным» [35, с. 19]. Известно также высказывание А. С. Пушкина, который отмечал, что писателя нужно судить по законам, им самим над собою признанным. 
Следует обратить внимание и на отличия трактовки крылатых выражений в русской и вьетнамской лингвокультурах. С точки зрения русской лингвокультуры, крылатые выражения возникли на базе авторского языкового материала, насыщенного образами, понятиями, а также на основе эмоционально окрашенных сочетаний слов, актуальность которых привела к их крылатизации. Во вьетнамской лингвокультуре крылатые выражения выступают в качестве устойчивых сочетаний слов или высказываний почитаемых исторических личностей, имеют философское значение, передаются народом из поколения в поколение. Важно обратить внимание на то, что во вьетнамской языковой традиции крылатые выражения имеют тесную связь с их создателем, в то время как в русской лингвокультуре наиболее популярные из них часто теряют связь с источником.

Крылатые выражения из комедии «Горе от ума» связаны с текстом, в котором были отражены настроения общества 10-20-х гг. XIX века. Большой талант А. С. Грибоедова, затронутые им общественные, политические, философские темы позволили создать произведение, крылатые выражения которого впитали В себя либеральные настроения социума. Национальные особенности понимания их значения основываются на культурно-исторической базе, имеющейся у человека, читающего комедию. С помощью приведенной выше таблицы мы можем увидеть, что в русском и вьетнамском языках существует большое количество схожих по своему смысловому наполнению крылатых выражений, что способствует более полному пониманию комедии. Однако религиозные, общественные традиции Вьетнама говорят о большей, чем в России, консервативности как молодых людей, так и старшего поколения. Историческое прошлое также оказало влияние на лингвокультуру Вьетнама, что способствовало появлению более традиционного отношения к вопросам уважения общества, к труду, пониманию влияния буддистских представлений о святости и доброте на жизнь человека.

Исследование научной литературы, сравнительно-описательный анализ крылатых выражений из комедии А. С. Грибоедова «Горе от ума» позволили прийти к следующим выводам:

1. Понятие «крылатое выражение» имеет схожую трактовку в русском и вьетнамском языках. В обоих языках понятие описывается как выразительная, часто употребляемая, устойчивая фраза образного или афористического характера, вошедшая в лексику из исторических, литературных источников. Различное понимание крылатых выражений заключается в том, что представители вьетнамской лингвокультуры воспринимают их смысл в контексте тесной связи с создателем, в то время как в русском языке личность автора по прошествии времени может не учитываться.

2. Русская и вьетнамская лингвокультурология рассматривают крылатые выражения как неотъемлемую часть культурного, литературного, исторического наследия общества. Крылатые выражения в русском языке часто употребляются вне связи с историческим контекстом их создания, в то время как во 
вьетнамской культуре их источник занимает одно из важнейших мест в его понимании.

3. Понимание крылатых выражений А. С. Грибоедова носителями вьетнамской лингвокультуры обычно связано с традициями, культурой, философией Вьетнама. Их восприятие имеет связь с религиозным, историческим, политическим прошлым и настоящим Вьетнама. Буддистское, фрилософское отношение к религии, уважительное, внимательное отношение к обязанностям, труду, воспитанное в рамках идеологической традиции, беспрекословное уважение старших, уходящее своими корнями в феодальное прошлое страны, иллюстрирует отношение носителя вьетнамской лингвокультуры к крылатым выражениям комедии, наполняя их особенным смыслом.

Таким образом, анализ крылатых выражений из комедии А. С. Грибоедова «Горе от ума» позволяет проследить важность учёта лингвокультурной традиции в процессе их восприятия. Различия в их трактовке, лингвокультурологическом описании и прочтении могут повлиять на понимание не только самих выражений, но также текста комедии в целом, наполняя её новыми оттенками смысла, связанного с национальным прошлым, традициями носителей русской и вьетнамской культур.

\section{СПИСОК ИСПОЛЬЗОВАННОЙ ЛИТЕРАТУРЫ}

1. Потебня А. А. Полное собрание трудов / А. А. Потебня. - М. : Мысль и язык, 1999. $-300 \mathrm{c}$.

2. Варченко Т. Г. К вопросу о терминологическом аппарате и становлении крылатологии как самостоятельной лингвистической дисциплины / Т. Г. Варченко, Л. А. Рачковская // Мир науки, культуры, образования. - 2013. - № 4. - С. 34-37.

3. Дядечко Л. П. Крылатые слова как объект лингвистического описания: история и современность : монография / Л. П. Дядечко. - Киев : Киев. нац. ун-т им. Тараса Шевченко, 2002. - 291 с.

4. Шулежкова С. Г. Крылатые выражения русского языка, их источники и развитие / С. Г. Шулежкова. - М. : Азбуковник, 2002. - 288 с.

5. Ngô Thị Thu Hải. Phép so sánh trong danh ngôn Việt Nam / Ngô Thị Thu Hải. — Thái Nguyên : Thái Nguyên tháng, 2012. - 120 p.

6. Nguyễn Như Ý. Đại từ điển tiếng Việt / Nguyễn Như Ý. — nxb Đại học Tổng hơp quốc gia tp. Hồ Chí Minh, 2009. - 500 p.

7. Đào Duy Anh. Từ điển Hán Việt / Đào Duy Anh. — Khoa học xã hội : Tp Hà Nội năm, 2003. - $659 \mathrm{p}$.

8. Hoàng Phê. Từ điển tiếng Việt, nxb Từ điển bách khoa, / Hoàng Phê. - Hà Nội : Viện Ngôn ngữ học, tp, 2010. - 538 p.

9. Võ Minh Hải. Văn Hoá Của Nam, Bắc Trong Ngôn Ngữ Văn Học Trung Đại Việt Nam [Electronic resource] / Võ Minh Hải. — Lundi, 2011. — 19 Décembre. — Mode of access:http:// www.hcmup.edu.vn/index.php?option=com_content\&view=article\&id=6701\%3Aham-nghavn-hoa-ca-nam-bc-trong-ngon-ng-vn-hc-trung-i-vit nam\&catid=4135\%3Ahan-nom\&ltemid=7 $246 \&$ lang $=$ fr\&site $=30$.

10. Nguyễn Thị Thu Thuỷ. Luận án Tiến sỹ Đaihọc sư phạm: Điển hình hoá trong văn xuôi hiện thực phê phán Việt Nam (giai đoạn 1930-1945), / Nguyễn Thị Thu Thuỷ. — Hồ Chí Minh, 2006. $-15 \mathrm{p}$.

11. Баранов А. Н. Аспекты теории фразеологии / А. Н. Баранов, Д. О. Добровольский. - М. : Знак, 2008. - 656 с. 
12. Беркова О. В. Крылатые слова и проблемы их лексикографирования : дис. канд. фрилол. наук : 10.02.19. / О. В. Беркова. - Л., 1991. - 161 с.

13. Виноградов В. В. Об основных типах фразеологических единиц в русском языке // Избранные труды. Лексикология и лексикография / В. В. Виноградов. - М. : Наука, 1977. - С. 140-161.

14. Гвоздарев Ю. А. Современный русский язык. Лексикология и фрразеология : учеб. пособие / Ю. А. Гвоздарев. - Ростов н/Д. : Изд-во Рост. ун-та, 2008. - 184 с.

15. Телия В. Н. Русская фразеология: семантический, прагматический и лингвокультурологический аспекты / В. Н. Телия. - М. : Шк. «Языки русской культуры, 1996. 288 c.

16. Шанский Н. М. Фразеология современного русского языка / Н.М. Шанский. — М. : Рус. яз., 2012. - 192 c.

17. Костомаров В. Г. Читая и почитая Грибоедова: Крылатые слова и выражения / В. Г. Костомаров, Н. Д. Бурвикова. - М. : Рус. яз., 1998. - 78 с.

18. Скогорев В. А. Афоризмы комедии «Горе от ума» А. С. Грибоедова / В. А. Скогорев // Сравнительно-исторические исследования русского языка. - Воронеж : Изд-во Воронеж. ун-та, 1980. - С. 123-128.

19. Полякова А. Е. Словарь языка А. С. Грибоедова / А. Е. Полякова. - М. : Книга по Требованию, 2011. - 430 с.

20. Мокиенко В. М. Большой словарь крылатых выражений А.С. Грибоедова («Горе от ума») / В. М. Мокиенко, О. П. Семенец, К. П. Сидоренко. - М. : ОЛМА Медиа Пресс, 2009. -800 c.

21. Винокур Г. О. Избранные работы по русскому языку / Г. О. Винокур. - М. : Учпедгиз, 1959. - 492 с.

22. Багратион-Мухранели И. Л. Традиции фольклора в русской комедии начала XIX и начала XX века. Грибоедов. Эрдман / И. Л. Багратион-Мухранели // Вестник Томского государственного педагогического университета. — 2011. - № 7. - С. 7-11.

23. Манолакев X. Грибоедов - Гоголь - Достоевский. Типология и герменевтика Слова / Х. Манолакев. - В. Търново : Фабер, 2011. - 182 с.

24. Сербул М. Н. «Горе от ума» А. С. Грибоедова: пути преодоления риторического слова / М. Н. Сербул // Политематический сетевой электронный научный журнал Кубанского государственного аграрного университета. — 2012. — № 81. - С. 978-990.

25. Сидоренко К. П. «Горе от ума» в русской речи / К. П. Сидоренко // Universum: Вестник Герценовского университета. - 2009. - № 11. - С. 40-45.

26. Воробьёв В. В. Лингвокультурология (теория и методы) : монография / В. В. Воробьёв. - М. : Изд-во Рос. ун-та дружбы народов, 1997. - 332 с.

27. Пак И. Я. Лингвокультурология как следствие процесса интеграции наук. Принципы лингвокультурологического анализа / И. Я. Пак // Молодежь и наука. Научная сессия МИФИ. - Томск : Том. гос. ун-т, 2012. - 183 с.

28. Шаклеин В. М. Лингвокультурная ситуация и исследование текста / В. М. Шаклеин. - М. : О-во любителей рос. словесности, 1997. - 184 с.

29. Телия В. Н. Что такое фразеология? / В. Н. Телия. - М. : Наука, 1966. - 86 с.

30. Ожегов С. И., Шведова Н. Ю. Толковый словарь русского языка. М. : ИТИ Технологии, 2008. - 928 с.

31. Пушкин А. С. Собрание сочинений : в 10 т. / А. С. Пушкин. - М. : Гослитиздат, 1962. - Т. 5. - 477 с. $256 \mathrm{c}$.

32. Грибоедов А. С. Горе от ума / А. С. Грибоедов. - М. : Олма Медиагрупп, 2012. -

33. Hoang Phe. Từ điển tiếng Việt : Từ điển bách khoa / Hoang Phe. - Hà Nội : Viện Ngôn ngũ̃ học, 2010. - 215 p.

34. Dao Duy Anh. Từ điển Hán Việt - nxb Khoa học xã hội / Dao Duy Anh. - Hà Nội : Khoa học xã hội, 2003. - 318 p.

35. Дмитриев М. А. Замечания на суждения «Телеграфра» // М. А. Дмитриев // Вестник Европы. - 1825. — № 6. - С. 19-23. 


\section{REFERENCES}

1. Potebnya A. A. Polnoe sobranie trudov [Complete Set of Works]. Moscow, Mysl' i yazyk Publ., 1999. 300 p.

2. Varchenko T. G., Rachkovskaya L. A. On the Issue of Terminology of Eloquent Phrases and Development of Phraseology of Eloquent Phrases as a Branch of Linguistics. Mir nauki, kul'tury, obrazovaniya = The World of Science, Culture, Education, 2013, no. 4, pp. 34-37. (In Russian).

3. Dyadechko L. P. Krylatye slova kak ob"ekt lingvisticheskogo opisaniya: istoriya i sovremennost' [Eloquent Words as an Object of Linguistic Description: A History and Modern Age]. Shevchenko Kiev National University Publ., 2002. 291 p.

4. Shulezhkova S. G. Krylatye vyrazheniya russkogo yazyka, ikh istochniki i razvitie [Eloquent Phrases in Russian, their Sources and Development]. Moscow, Azbukovnik Publ., 2002. 288 p.

5. Ngô Thị Thu Hải. luận văn thạc sĩ của Ngô Thị Thu Hải "Phép so sánh trong danh ngôn Việt Nam" trường Đh sư phạm Thái Nguyên - Thái Nguyên tháng 5-2012, 120 p.

6. Nguyen Nhu Y. Đại từ điển tiếng Việt - nxb Đại học Tổng hơp quốc gia tp. Hồ Chí Minh,năm, 2009. 500 p.

7. Dao Duy Anh. Từ điển Hán Việt — nxb Khoa học xã hội. Tp Hà Nội năm 2003. 659 p.

8. Hoang Phe. Từ điển tiếng Việt - nxb Từ điển bách khoa, Viện Ngôn ngữ học, tp.Hà Nội, năm 2010. 538 p.

9. Võ Minh Hải Hàm Nghĩa Văn Hoá Của Nam, Bắc Trong Ngôn Ngữ Văn Học Trung Đại Việt Nam, Lundi, 19 Décembre, 2011. Available at: http://www.hcmup.edu.vn/index. php?option $=$ com_content $\&$ view $=$ article $\&$ id $=6701 \% 3$ Aham-ngha-vn-hoa-ca-nam-bctrong-ngon-ng-vn-hc-trung-i-vit nam\&catid=4135\%3Ahan-nom\&ltemid=7246\&lang=fr\&si te $=30$. (In Vietnamese).

10. Nguyễn Thị Thu Thuỷ. Luận án Tiến sỹ: Điển hình hoá trong văn xuôi hiện thực phê phán Việt Nam (giai đoạn 1930-1945), Đai học sư phạm tp Hồ Chí Minh, năm 2006. 15 p.

11. Baranov A. N., Dobrovol'skii D. O. Aspekty teorii frazeologii [Some Aspects of the Theory of Phraseology]. Moscow, Znak Publ., 2008. 656 p.

12. Berkova O. V. Krylatye slova i problemy ikh leksikografirovaniya. Kand. Diss. [Eloquent Words and Related to them Lexicographical Issues. Cand. Diss.]. Leningrad, 1991. $161 \mathrm{p}$.

13. Vinogradov V. V. On the Main Types of Phraseological Units in the Russian Language. In Vinogradov V. V. Izbrannye trudy. Leksikologiya i leksikografiya [Selected Works. Lexicology and Lexicography]. Moscow, Nauka Publ., 1977, pp. 140-161. (In Russian).

14. Gvozdarev Yu. A. Sovremennyy russkiy yazyk. Leksikologiya i frazeologiya [Modern Russian. Lexicology and Phraseology]. Rostov-on-Don, Rostov University Publ., 2008. 184 p.

15. Teliya V. N. Russkaya frazeologiya: Semanticheskii, pragmaticheskii i lingvokul'turologicheskii aspekty [Russian Phraseology: the Semantic, Pragmatic and Linguocultural Aspects]. Moscow, Languages of Russian Culture School Publ., 1996. 288 p.

16. Shanskii N. M. Frazeologiya sovremennogo russkogo yazyka [Phraseology of Modern Russian]. Moscow, Russkii yazyk Publ., 2012. 192 p.

17. Kostomarov V. G., Burvikova N. D. Chitaya i pochitaya Griboedova: Krylatye slova $i$ vyrazheniya [Reading and Respecting Griboyedov: Eloquent Words and Phrases]. Moscow, Russkii yazyk Publ., 1998. 78 p.

18. Skogorev V. A. Aphorisms from the Comedy Woe from Wit by Alexander S. Griboyedov. Sravnitel'no-istoricheskie issledovaniya russkogo yazyka [Comparative-Historical Studies of Russian]. Voronezh University Publ., 1980, pp. 123-128. (In Russian).

19. Polyakova A. E. Slovar' yazyka A. S. Griboedova [Alexander S. Griboyedov's Language Dictionary]. Moscow, Kniga po Trebovaniyu Publ., 2011. 430 p.

20. Mokienko V. M., Semenets O. P., Sidorenko K. P. Bol'shoy slovar'krylatykh vyrazheniy A. C. Griboedova ("Gore ot uma») [Alexander S. Griboyedov's Eloquent Phrases from Woe from Wit Big Dictionary]. Moscow, OLMA Media Press, 2009. 800 p.

21. Vinokur G. O. Izbrannye raboty po russkomu yazyku [Selected Works on the Russian Language]. Moscow, Uchpedgiz Publ., 1959. 492 p. 
22. Bagration-Mukhraneli I. L. Folklore Traditions in the Russian Comedy of the Beginning of the $19^{\text {th }}$ Century and the Beginning of the $20^{\text {th }}$ Century. Griboyedov. Erdman. Vestnik Tomskogo gosudarstvennogo pedagogicheskogo universiteta $=$ Tomsk State Pedagogical University, 2011, no. 7, pp. 7-11. (In Russian).

23. Manolakev Kh. Griboedov - Gogol'-Dostoevskiy. Tipologiya i germenevtika Slova [Griboyedov - Gogol - Dostoevsky. Typology and Hermeneutics of the Word. V. T"rnovo, Faber Publ., 2011. 182 p.

24. Serbul M. N. Woe from wit by A. Griboyedov. The ways of overcoming rhetoric. Politematicheskii setevoi elektronnyi nauchnyi zhurnal Kubanskogo gosudarstvennogo agrarnogo universiteta = Polythematic Online Scientific Journal of Kuban State Agrarian University, 2012, no. 81, pp. 978-990. (In Russian).

25. Sidorenko K. P. Woe from Wit in Spoken Russian. Universum: Vestnik Gertsenovskogo universiteta = Universum, 2009, no. 11, pp. 40-45. (In Russian).

26. Vorob'ev V. V. Lingvokul'turologiya (teoriya i metody) [Linguoculturology (Theory and Methods)]. Moscow, People's Friendship University of Russia Publ., 1997. 332 p.

27. Pak I. Ya. Linguoculturology as a Result from Sciences Integration. Principles of Linguocultural Analysis. Molodezh'i nauka. Nauchnaya sessiya MIFI [The Youth and Science. MEPhl's Workshop]. Tomsk State University Publ., 2012. 183 p. (In Russian).

28. Shaklein V. M. Lingvokul'turnaya situatsiya $i$ issledovanie teksta [Linguocultural Situation and Text Studies]. Moscow, Russian Philology Society Publ., 1997. 184 p.

29. Teliya V. N. Chto takoe frazeologiya? [What is Phraseology?]. Moscow, Nauka Publ., 1966. $86 \mathrm{p}$.

30. Ozhegov S. I., Shvedova M. Yu. (ed.) Slovar russkogo yazyka [Dictionary of the Russian Language]. Moscow, ITI Tekhnologii Publ., 2008. 928 p.

31. Pushkin A. S. Sobranie sochinenii [Collection of Works]. Moscow, Goslitizdat Publ., 1962. Vol. 5. 477 p. $256 \mathrm{p}$

32. Griboedov A. S. Gore ot uma [Woe from Wit]. Moscow, Olma Mediagrupp Publ., 2012.

33. Hoang Phe. Từ điển tiếng Việt - nxb Từ điển bách khoa, Viện Ngôn ngữ học, tp.Hà Nội, năm 2010. 215 p.

34. Dao Zuy Anh. Từ điển Hán Việt — nxb Khoa học xã hội. Tp Hà Nội năm 2003. 318 p.

35. Dmitriev M. A. Remarks on The Telegraph Judgements. Vestnik Evropy = Europe's Bulletin, 1825, no. 6, pp. 19-23. (In Russian).

\section{Библиографическое описание статьи}

Шаклеин В. М. Информативный компонент крылатых выражений комедии А. С. Грибоедова «Горе от ума» с позиции вьетнамской языковой традиции / В. М. Шаклеин, Нгуен Лан Фыонг // Вопросы теории и практики журналистики. - 2017. T. 6, № 3. — C. 388-405. — DOI: 10.17150/2308-6203.2017.6(3).388-405.

\section{Reference to article}

Shaklein V. M., Nguyen Phuong Lan. Informational Component of Eloquent Expressions in A. S. Griboedov's Comedy "Gore Ot Uma» (Woe from Wit) in the Aspect of Vietnamese Language Tradition. Voprosy teorii i praktiki zhurnalistiki $=$ Theoretical and Practical Issues of Journalism, 2017, vol. 6, no. 3, pp. 388-405. DOI: 10.17150/2308-6203.2017.6(3).388-405. (In Russian). 